\title{
GEOTECNOLOGIAS APLICADAS NA AVALIAÇÃO DA ADEQUABILIDADE DA ÁREA DE ATERRO SANITÁRIO: UM ESTUDO NO MUNICÍPIO DE PRESIDENTE BERNARDES - SP
}

\section{GEOTECHONOLOGIES APPLIED TO SUITABILITY EVALUATION OF LANDFILL AREA LANDFILL: A CASE OF STUDY IN THE CITY OF PRESIDENTE BERNARDES, SP}

\author{
Alessandra Santos ; Lucas Prado Osco ; Ana Paula Marques Ramos ${ }^{3}$ \\ Universidade do Oeste Paulista - UNOESTE, ${ }^{1}$ Engenharia Ambiental e Sanitária; \\ ${ }^{2}$ Doutorado em Agronomia; ${ }^{3}$ Mestrado em Meio Ambiente e Desenvolvimento \\ Regional \\ E-mail: $\quad$ alessandrasantos12@hotmail.com ${ }^{1}$; $\quad$ pradoosco@gmail.com ${ }^{2}$; \\ anaramos@unoeste.br ${ }^{3}$
}

RESUMO - A seleção de áreas para aterros sanitários deve atender a diversos critérios estabelecidos em legislação e por órgãos ambientais para minimizar impactos ambientais. Este trabalho avalia a adequação da área do aterro de resíduo sólido no município de Presidente Bernardes - SP, no Pontal do Paranapanema. O método se consistiu da: revisão dos parâmetros para adequabilidade de locais de instalação de aterro; elaboração de cartas temáticas e da carta síntese para avaliação da área do aterro. Na produção das cartas, utilizou-se dados cartográficos disponibilizados, gratuitamente, usando software de Sistema de Informação Geográfica. Aplicou-se a inferência geográfica por lógica booleana na geração da carta síntese. Conclui-se que a área do aterro está inadequada por não atender a todos os parâmetros requeridos pela legislação brasileira. Recomenda-se o uso de outros métodos de inferência geográfica, como a média ponderada. Palavras-chave: Cartas Temáticas; Aterro Sanitário; Inferência.

ABSTRACT - The selection of areas for implementation and operation of landfills must meet several legal criteria to minimize the environmental impacts. This study evaluates the adequacy of the solid waste landfill area in the municipality of Presidente Bernardes - SP, in Pontal do Paranapanema. The method consisted of a review of the parameters for suitability of landfill installation locations, making thematic maps and synthesis map for assessment of the landfill area. It was used free data available from Brazilian authorities. Maps were produced using a Geographic Information System software. The Boolean logic was adopted in the geographic inference process to make the synthesis map. We conclude that area of the landfill is

Recebido em: 01/07/2016 Revisado em: 09/08/2016 Aprovado em: 25/08/2016 inadequate because it does not meet all the parameters required by the Brazilian laws. It is suggested to apply other geographic inference methods such as the weighted average.

Keywords: Thematic Maps; Landfill; Environmental Impacts; Inference. 


\section{INTRODUÇÃO}

A preservação e conservação dos recursos naturais são importantes para a garantia da qualidade ambiental e, consequentemente, a sobrevivência humana. Uma das maiores problemáticas em relação à preservação do meio ambiente é a geração de resíduos sólidos, a qual tende a crescer com o aumento e a forma de consumo da população. Os resíduos, quando descartados de forma inadequada, podem alterar direta ou indiretamente a qualidade do ar, solo e água. A maneira, atualmente, de se minimizar os impactos ambientais na destinação dos resíduos sólidos, uma vez que não podem ser aproveitados ou reciclados, é a disposição em aterros sanitários.

Segundo Moreira (2002), a determinação de áreas adequadas para a implantação dos aterros sanitários é um processo complexo devido à composição dos resíduos, a qual sofre constante mudanças conforme o avanço tecnológico. Por essa razão, em diferentes países se adota distintos critérios sobre a decisão de locais para a implantação de aterros sanitários. Os locais adequados para a disposição final de resíduos sólidos devem atender a todas as etapas do processo da atividade do empreendimento, desde a área apta para implantação até a fase de encerramento das atividades do aterro sanitário (LINO, 2007).
No ano de 1997, a Associação Brasileira de Normas Técnicas (ABNT) criou a Norma Brasileira de Referência (NBR) número 13.896 que estabelece os critérios para seleção e adequação de áreas para aterros sanitários. Cabe ressaltar que a Portaria Minter 124, de 1980, e o Conselho Nacional do Meio Ambiente (CONAMA), nas resoluções de 1990 e 1995, também, apresentam alguns critérios sobre a adequabilidade de áreas para aterros sanitários. Além disso, no Estado de São Paulo, há recomendações da Companhia Ambiental do Estado de São Paulo (CETESB). Dentre os critérios para adequação de áreas para aterros sanitários critérios incluem-se a distância mínima da drenagem, do perímetro urbano, de aeródromo e a declividade do terreno, bem como há uma recomendação para a distância mínima até as rodovias.

Sendo assim, a seleção de áreas para a implantação e a operação de aterros de resíduos sólidos deve atender a critérios estabelecidos em legislação e por órgãos ambientais, a fim de minimizar os impactos decorrentes dessa atividade antrópica. A avaliação desses parâmetros indicará os locais aptos e não-aptos à instalação desse tipo de empreendimento. Entretanto, ainda hoje, há uma grande dificuldade por parte dos municípios em atender aos critérios sistematizados na legislação brasileira e por órgãos ambientais ao definir um local para a 
instalação de um aterro. Entende-se que para atender às exigências legais em vigor, bem como as recomendações, seja em âmbito estadual ou federal, deve-se processar e integrar diferentes dados cartográficos referentes ao local do aterro. Esta tarefa pode ser otimizada por meio do uso de software de Sistema de Informação Geográfica (SIG) e de ferramentas de Geoprocessamento, facilitando o processo de avaliação da adequação de áreas para aterros sanitários.

Esse trabalho avalia a adequabilidade da área onde se localiza o aterro de resíduos sólidos no município de Presidente Bernardes - SP. A principal contribuição é auxiliar na verificação da adequação de locais para instalação e operação de aterros sanitários, visando reduzir os impactos para o meio ambiente e os seres que nele vivem.

\section{METODOLOGIA}

O método consiste de três etapas: revisão dos parâmetros de adequabilidade para instalação de aterro sanitário descritos na legislação brasileira e por órgãos ambientais; elaboração de cartas temáticas para esses parâmetros de restrição e produção de carta síntese para avaliação do local onde se encontra o aterro sanitário de Presidente Bernardes. Os parâmetros estudados são os apresentados na Portaria Minter 124 (1980), na NBR 13.896 (1997), na resolução CONAMA (1990/1995), bem como as recomendações da CETESB (2014).

\section{Área de Estudo}

O aterro sanitário em estudo está localizado na bacia hidrográfica do córrego do Guaiçara, a qual se encontra entre os municípios de Presidente Bernardes e Álvares Machado - SP, totalizando uma área de 165,7 km2 (Figura 1).

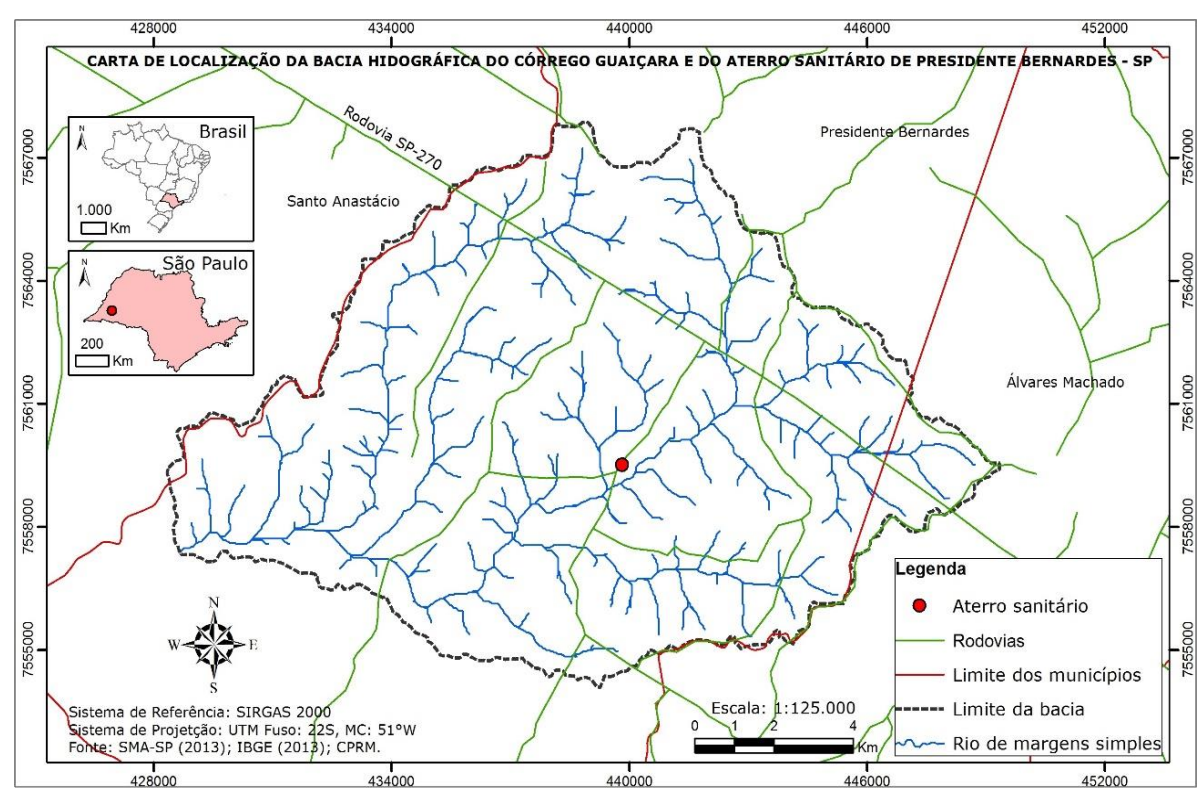

Figura 1. Localização do aterro sanitário na bacia do córrego do Guaiçara. 


\section{Produção das cartas temáticas: de restrição e carta síntese}

As cartas temáticas foram elaboradas com dados disponibilizados, gratuitamente, por órgãos brasileiros, utilizando software de SIG. Alguns dos dados encontram-se em formato vetorial, armazenados em arquivos shapefile, outros em formato matricial, armazenados em arquivos imagem. Todas as cartas temáticas, de restrição e de síntese, foram elaboradas na escala de 1:150.000 e exibidas com uma imagem do satélite LANDSAT 8 (sensor OLI) de plano de fundo, em formato A4.

Um total de cinco cartas temáticas de restrição foi produzido, sendo as quais: distância mínima da drenagem, perímetro urbano, aeródromo e declividade do terreno, além de distância mínima de rodovias. Tais cartas contêm faixas de distância representando as áreas restritas à instalação do aterro sanitário em Presidente Bernardes. Essas faixas foram definidas usando a ferramenta de Geoprocessamento "faixa de distância" (buffer).

Para produzir a carta de restrição à drenagem, utilizou-se o seguinte critério: qualquer atividade altamente impactante com distância inferior a 200 metros de todo curso d'água consiste estar em uma área de restrição à drenagem, conforme a Portaria Minter 124/1980. Os dados de rede de drenagem utilizados são os disponibilizados pela Secretaria do Meio Ambiente em 2013. Para a carta de restrição ao sistema viário, adotou-se o valor de 200 metros de distância das vias de acesso ao aterro sanitário. Esse valor de distância é baseando nas abordagens de Weber e Hasernack (2002) e Born (2013), bem como nas recomendações da CETESB (2014). Nesta carta, utilizou-se os dados de trecho de rodovias disponibilizados pelo Instituto Brasileiro de Geografia e Estatística (IBGE) para o ano de 2013.

Quanto à elaboração da carta de restrição ao perímetro urbano, nesta foi estabelecida uma faixa de distância de 500 metros a partir do limite urbano para caracterizar a área de restrição, com base no exigido pela NBR 13896 (1997). Utilizou-se arquivos vetoriais do IBGE, ano de 2013.

$\mathrm{Na}$ carta de restrição às Unidades de Conservação, utilizaram-se dados vetoriais extraídos do banco de dados da Serviço Geológico do Brasil (CPRM) disponíveis através da base GEOBANK. A resolução CONAMA 13 (1990) estabelece uma distância de 10 quilômetros a partir do limite da Unidade de Conservação para instalação de aterros sanitários, sendo restritas as áreas inferiores a essa faixa de distância.

Para a produção da carta de restrição a aeródromo, foi adotada a resolução CONAMA 04 (1995), a qual fixa a distância de 20 quilômetros entre aterros sanitários e as áreas aeroportuárias para voos 
instrumentais, 13 quilômetros para as demais áreas de pouso. Os arquivos utilizados na elaboração dessa carta são os disponibilizados pelo IBGE, ano de 2013.

A carta de restrição à declividade foi elaborada com dados de radar, imagem SRTM (Shuttle Radar Topography Mission), ano de 2014, disponibilizados pela Empresa Brasileira de Pesquisa Agropecuária EMBRAPA. Definiram-se as seguintes classes de declividade: menor que $1 \%$; de $1 \%$ até $30 \%$; maior que $30 \%$. Tais critérios atendem à
NBR 13896 (1997) que dispõe que áreas adequadas para a implantação de aterros sanitários tenham declividade maior que $1 \%$ e inferior a $30 \%$.

A elaboração da carta temática de síntese ocorreu a partir das cartas de restrição aplicando álgebra de mapas por lógica booleana. O fluxograma na Figura 2 resume o método empregado tanto na elaboração desta carta quanto nas cartas temáticas de restrição.

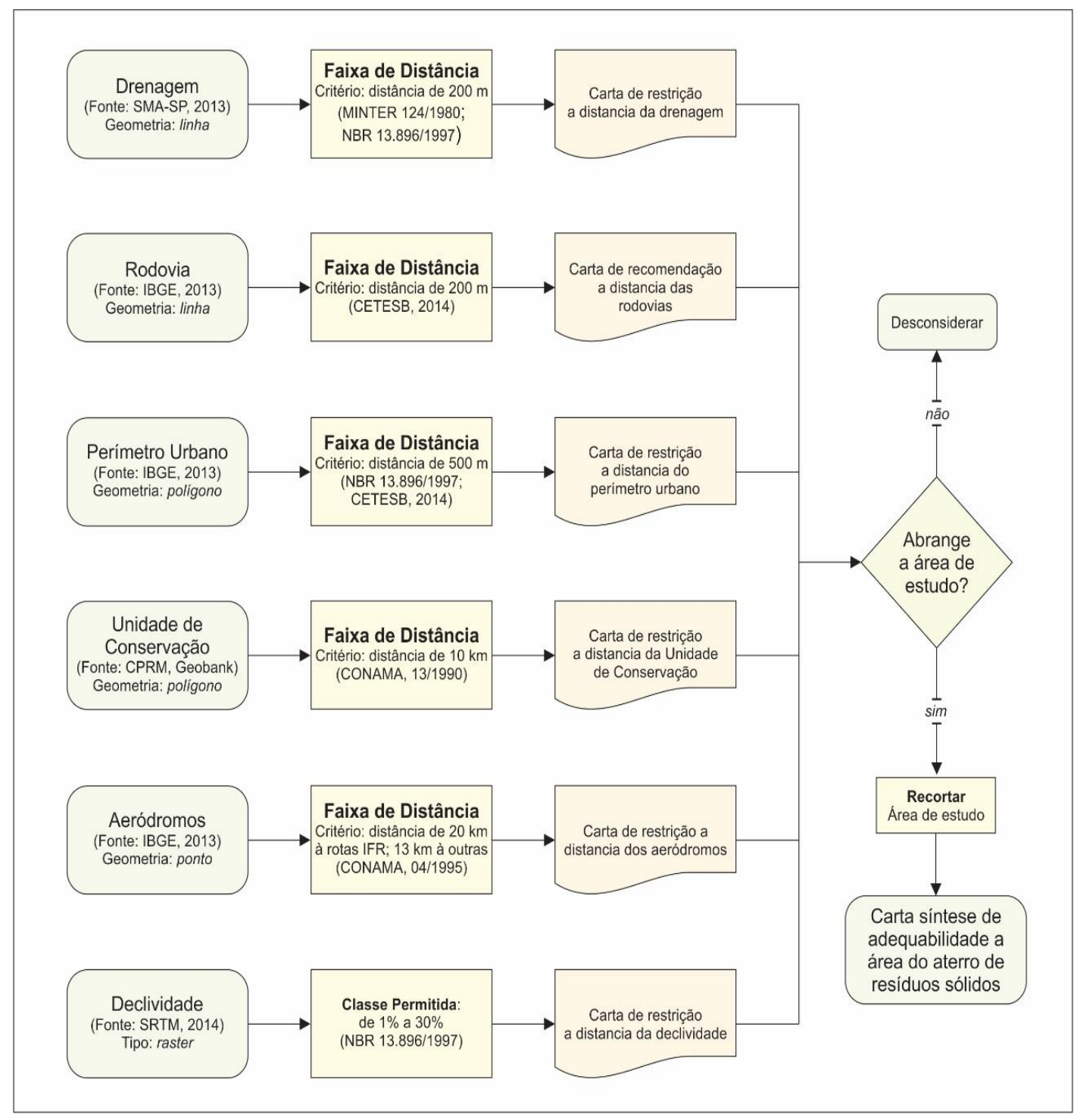

Figura 2. Fluxograma para avaliação da adequabilidade de áreas de aterro sanitário. 


\section{RESULTADOS}

A Figura 3 apresenta a carta de restrição à drenagem da bacia hidrográfica do córrego do Guaiçara, associado aos cursos d'água presentes nesta bacia. Conforme adotado no método, criou-se um buffer de 200 metros em todos cursos d'água mapeados. Observa-se que a faixa de distância entre 0 aterro sanitário de Presidente Bernardes e os corpos d'água superficiais encontra-se em local legalmente aceitável no que é estabelecido pela portaria Minter $124 / 80$. Isto é um fator importante, pois viabiliza a prevenção de acidentes por substâncias altamente capaz de causar poluição hídrica, como no caso o chorume.

$\mathrm{Na}$ Figura 4, tem-se a carta de recomendação ao sistema viário, bem como as rodovias de acesso ao aterro sanitário. Verificou-se que a área do aterro se situa dentro da faixa de restrição de 200 metros. Como pode-se observar na carta (Figura 4), o aterro está instalado nas margens de uma das rodovias, o que evidencia que o mesmo não se encontra em local adequado.

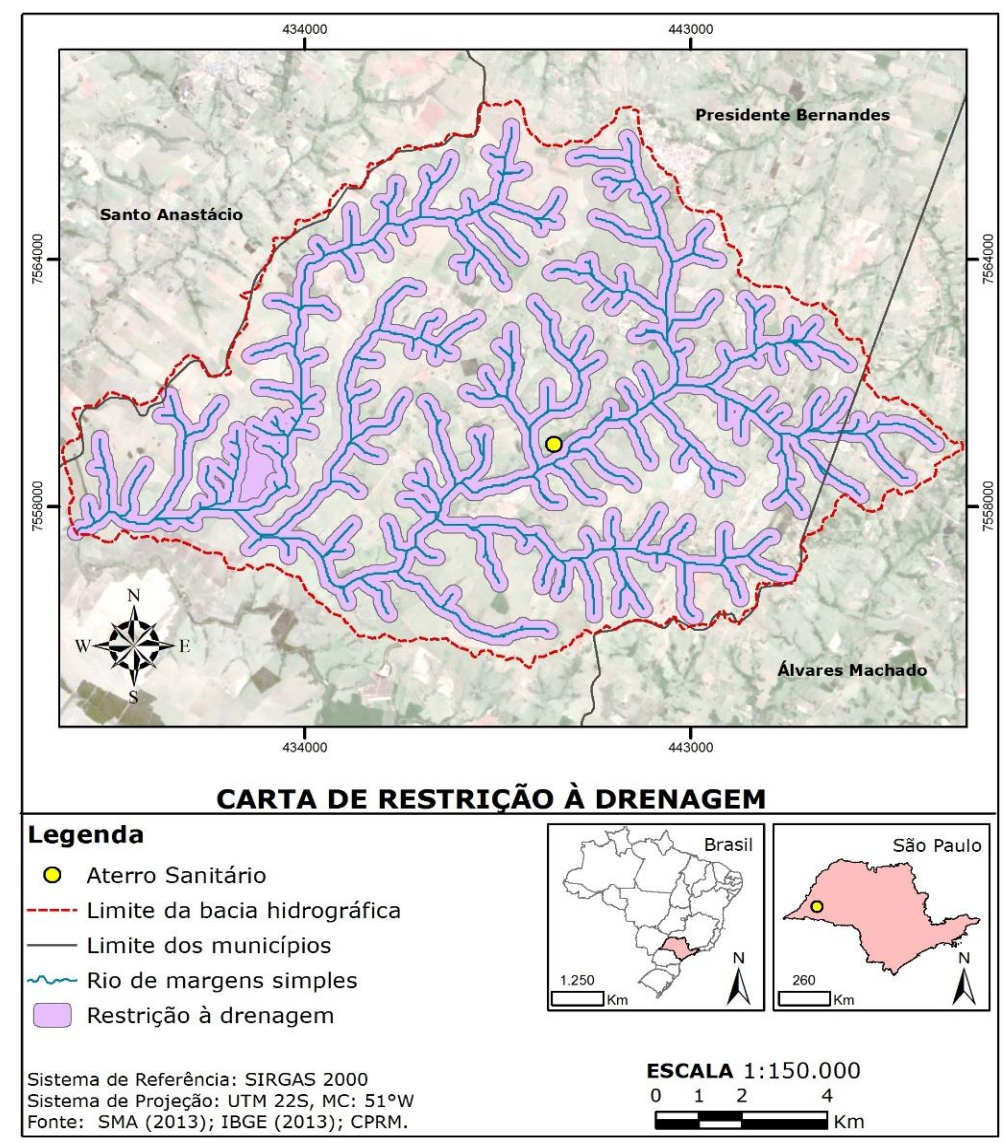

Figura 3. Carta de restrição à drenagem. 


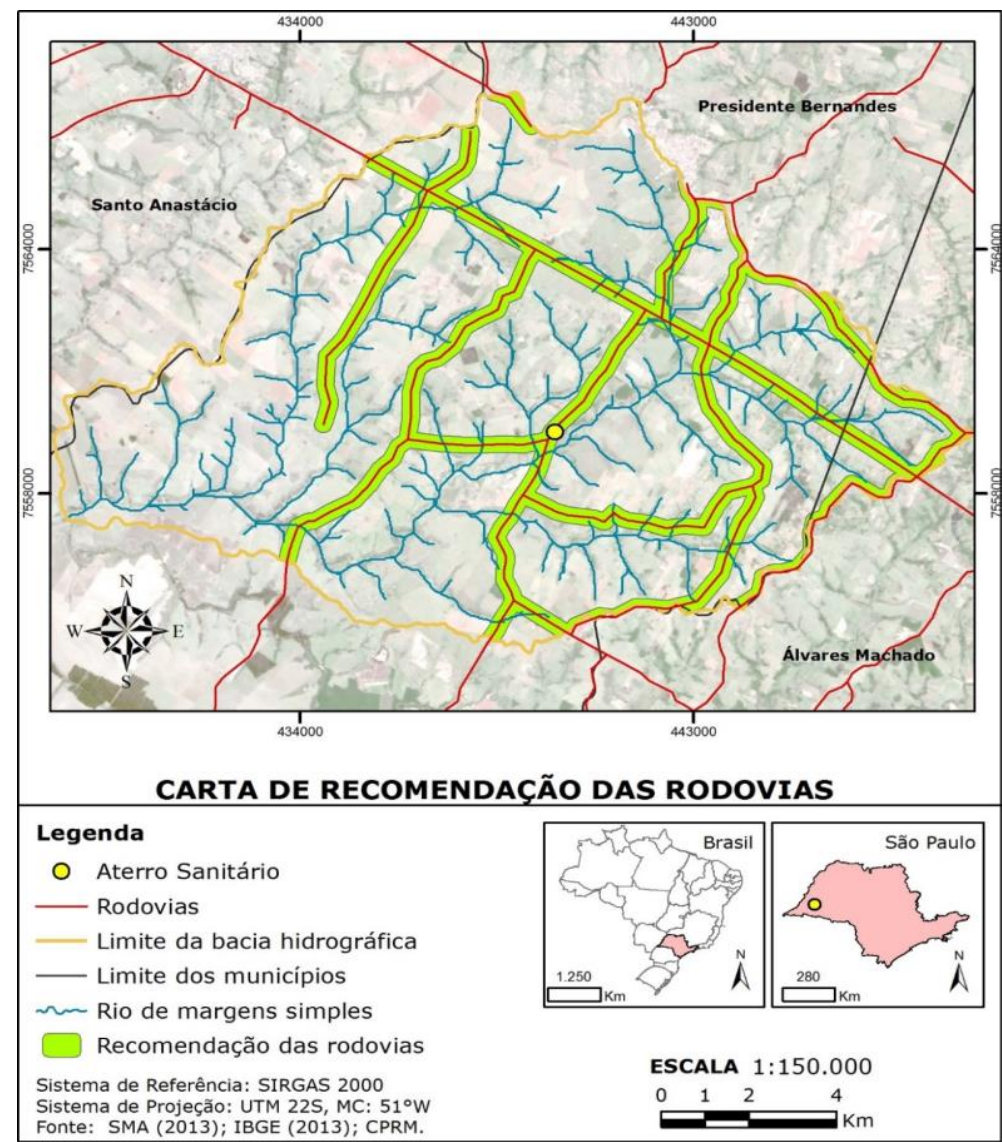

Figura 4. Carta de restrição das rodovias.

A Figura 5 apresenta a carta de restrição ao perímetro urbano, do qual foi aplicado uma faixa de distância de 500 metros conforme a NBR 13896 (1997). Notase que, para este parâmetro, o aterro está instalado em um local legalmente permitido. Este é um resultado esperado, visto que a população tem resistência quanto à instalação de aterros próximos às áreas urbanizadas, pois há preocupação com odores desagradáveis, ruídos, poeira, proliferação de insetos e outros vetores de doença.

A restrição às Unidades de Conservação não abrange a área de estudo, portanto, não se elaborou uma carta temática para este parâmetro de restrição. Na carta de restrição aos aeródromos (Figura 6), aplicou-se a faixa de 13 e 20 quilômetros conforme a resolução CONAMA 04 (1995). O artigo 2ㅇ desta resolução dispõe que não será permitida atividades de natureza perigosa, entendidas por serem "foco de atração de pássaros" proporcionando riscos a navegação aérea. Constata-se, pela Figura 6, que área do aterro sanitário em estudo está em área de restrição. Portanto, verificou-se, que há uma pequena parcela da área livre da restrição de aeródromos para instalação e operação de aterros sanitários. 


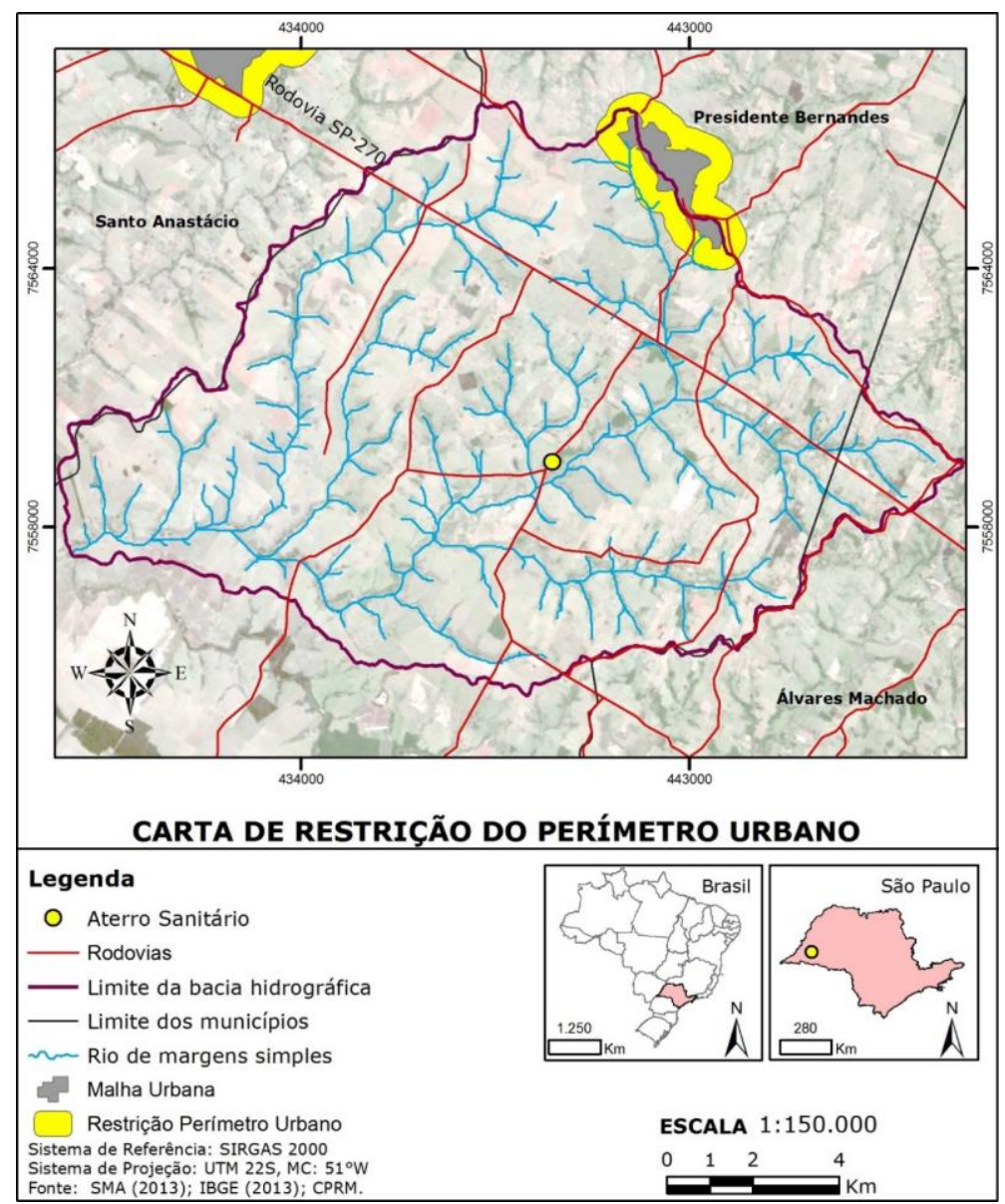

Figura 5. Carta de restrição do perímetro urbano.

Na Figura 7 tem-se a carta de restrição da declividade. Nota-se que a área da bacia é uma região com relevo predominantemente plano, portanto o aterro sanitário está instalado em um local legalmente aceitável segundo a NBR 13896 (1997). A declividade está diretamente ligada com a capacidade de escoamento do percolado, assim quanto menor for a declividade do terreno mais apta será a área para implantação de um aterro.

O resultado da carta síntese encontrase apresentado na Figura 8. Para tanto, fez-se a álgebra, por lógica booleana, das seguintes cartas de restrição: à drenagem, perímetro urbano, aeródromos e a carta de recomendação ao sistema viário. Optou-se por não considerar na composição da carta síntese a restrição dos aeródromos de distanciamento de 13 quilômetros, pois abrange grande parte da área da bacia, o que não permitiria uma visualização das demais restrições.

A declividade, por sua vez, resultou em áreas restritas de menor expressão, e por esta razão não se considerou adequado apresenta-las na escala final. A carta síntese evidencia que, de forma legal, o local do aterro sanitário de Presidente Bernardes encontra-se em uma área inadequada. 


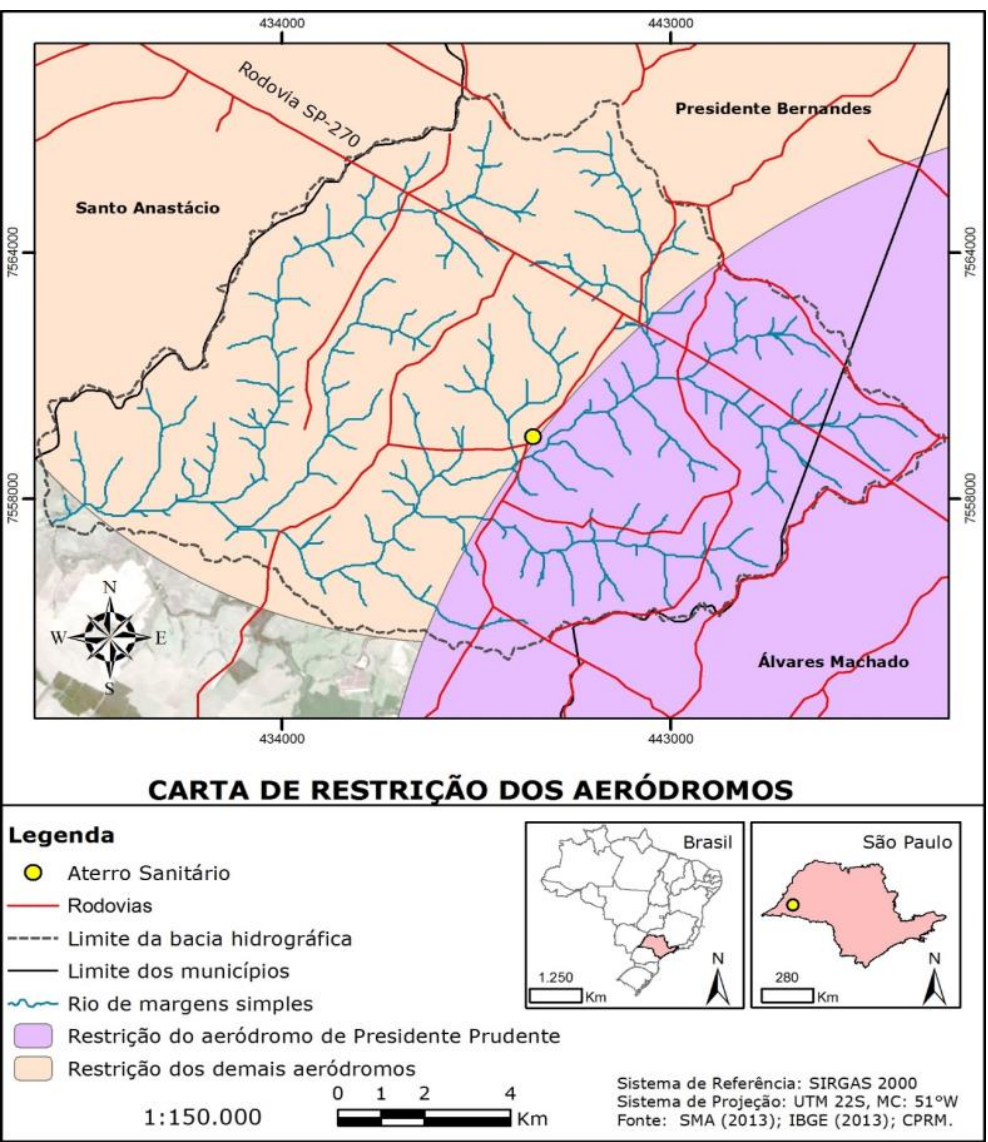

Figura 6. Carta de restrição dos aeródromos.

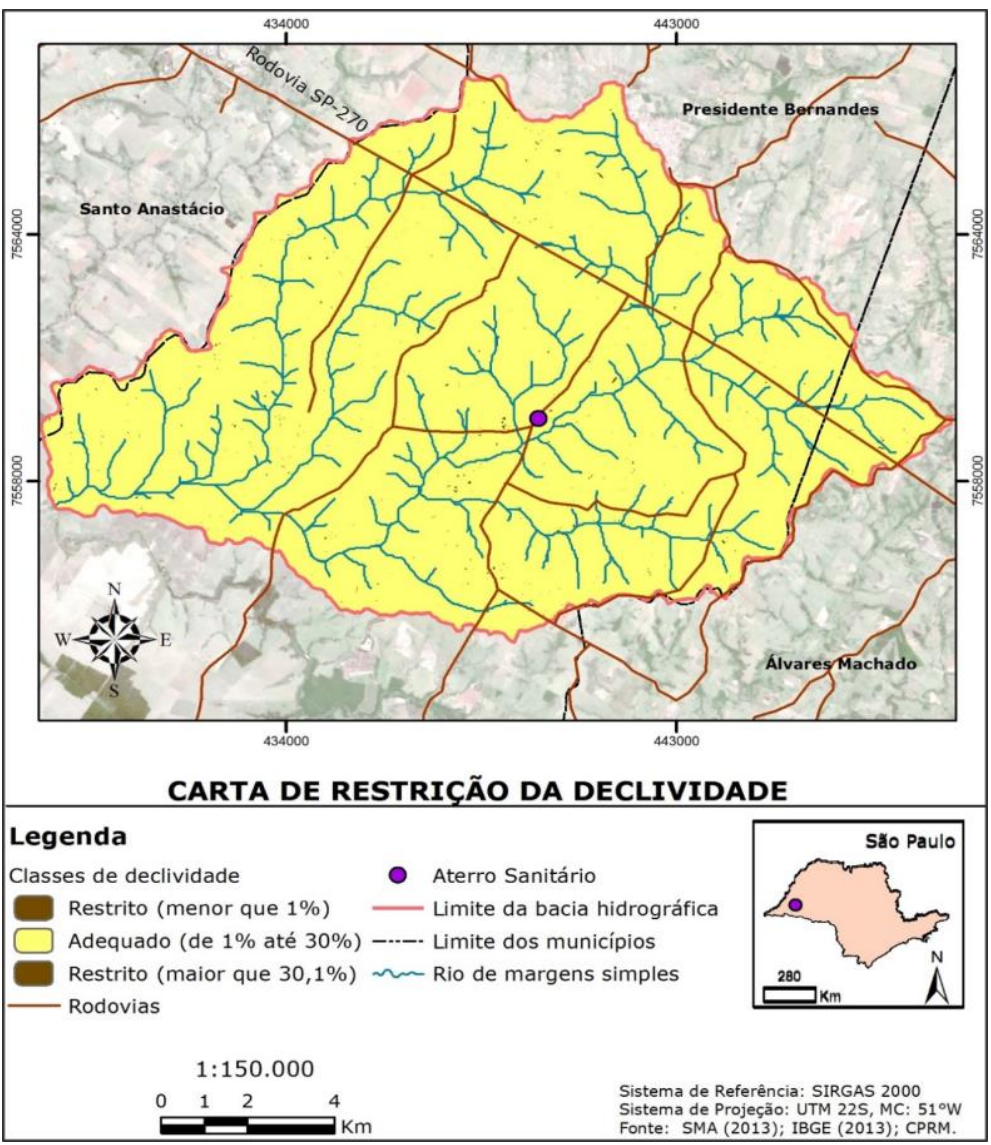

Figura 7. Carta de restrição da declividade. 


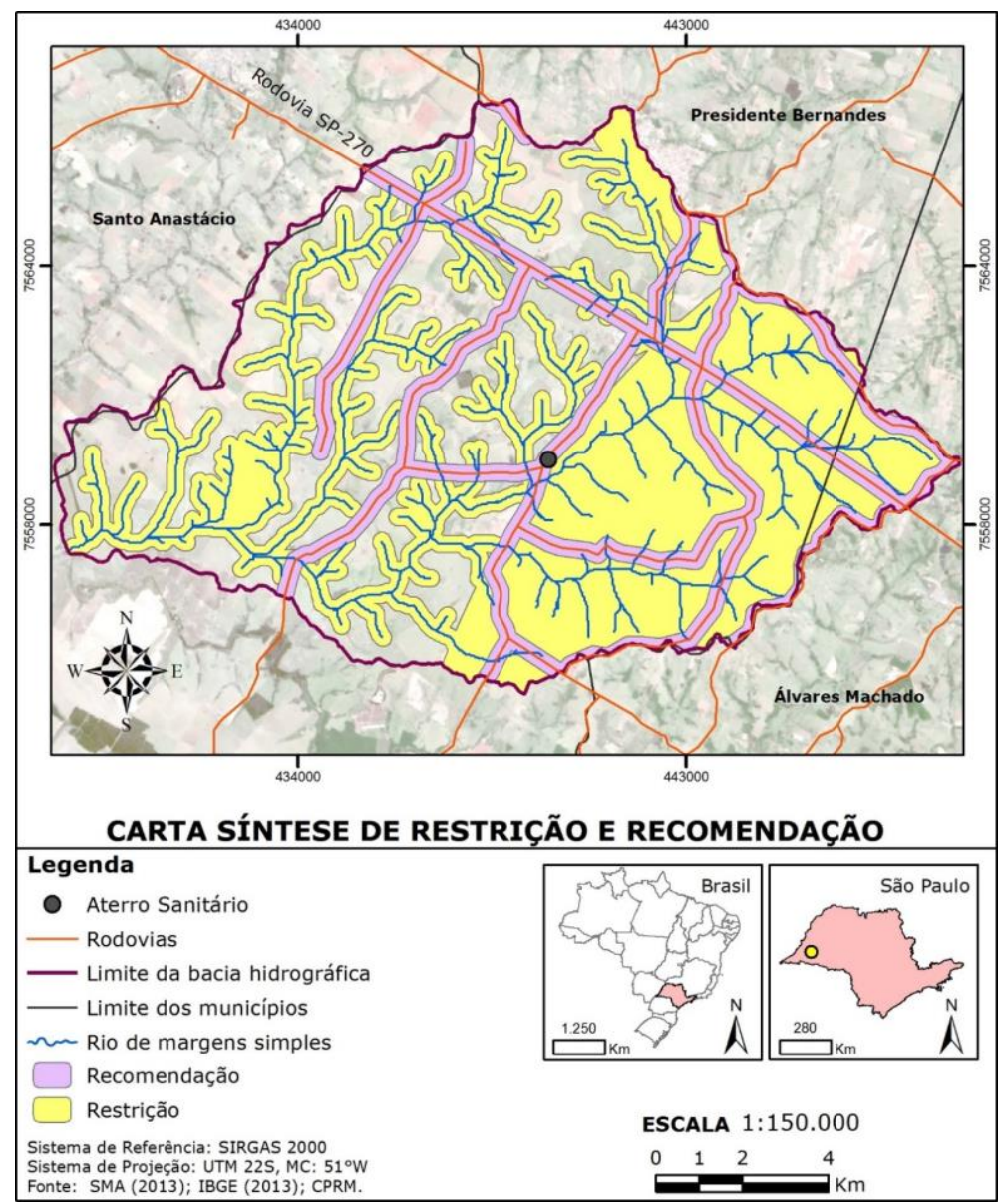

Figura 8. Carta síntese de restrição e recomendação.

\section{DISCUSSÃO}

A partir das cinco cartas temáticas, se realizou a construção da carta síntese, sendo possível avaliar a área da bacia do córrego do Guaiçara em sua totalidade. Na sobreposição dos dados de cada carta é possível visualizar os locais onde são restritos a instalação de aterros sanitários, tornando mais fácil a seleção de uma provável área adequada a esse tipo de atividade.

Os critérios atendidos pelo local em estudo foram a restrição quanto à distância mínima para a drenagem e para o perímetro urbano, enquanto a recomendação de rodovias e restrição dos aeródromos não foram atendidas.

\section{CONSIDERAÇÕES FINAIS}

A seleção de áreas adequadas para a instalação de aterro sanitário de resíduos sólidos é um trabalho complexo, sendo necessário uma avaliação diferenciada para cada restrição devido a particularidades dos parâmetros restritivos. No geral, essas restrições contemplam um conjunto de critérios e medidas que visam principalmente a proteção do bem ambiental. Conclui-se que o uso de software de SIG e das ferramentas de Geoprocessamento foram importantes 
para otimizar o processo de avaliação da adequabilidade da área do aterro sanitário, mediante aos parâmetros legislativos e as recomendações. Os resultados dessa investigação inicial, decorrentes da aplicação de Geotecnologias e da legislação brasileira, sugerem a conclusão de que a área do atual aterro do município d Bernardes pode ser caracterizada como uma área legalmente inadequada para receber tal atividade antrópica. Todavia, recomenda-se a realização de novos estudos, utilizando outros métodos de inferência geográfica, tal como a média ponderada, os quais aplicam pelos às variáveis. Uma vez corroborados esses resultados com os apresentados neste trabalho, sugere-se a seleção de um novo local para o aterro do município de Presidente Bernardes.

Ressalta-se que o método de inferência geográfica aplicado, o booleano, define a área do aterro como adequada ou não, seguindo as leis de esfera Federal e Estadual. Entretanto, não garante uma avaliação aprofundada de fatores que ambientalmente, também, devem ser considerados, como a qualidade do solo, profundidade do lençol freático, dentre outros parâmetros geotécnicos. Sendo assim, recomenda-se que, além das restrições levantadas no presente estudo, considere-se a capacidade do meio físico em suportar o empreendimento (aterro sanitário).

\section{REFERÊNCIAS}

ABNT NBR 13896. Aterro de resíduos não perigosos - Critérios para projeto, implantação e operação. Rio de Janeiro: ABNT, 1997.

BORN, V. Avaliação da aptidão de áreas para a instalação de aterro sanitário com o uso de ferramentas de apoio à decisão por múltiplos critérios. Lajeado: Centro Universitário Univates, 2013. Disponível em: $<$ https://www.univates.br/bdu/bitstream/10 737/374/1/VivianeBorn.pdf>. Acesso em 09 abr. 2016.

BRASIL. Portaria Minter 124/1980. Estabelece normas para a localização de indústrias potencialmente poluidoras junto às coleções hídricas. Disponível em: $<$ http://ima.al.gov.br/wpcontent/uploads/2015/03/Portaria-nb0124.80.pdf>. Acesso em: 09 abr. 2016.

BRASIL. Resolução CONAMA 13/1990. Estabelece normas referentes ao entorno das Unidades de Conservação visando a proteção dos ecossistemas ali existentes. Disponível em: <http://ima.al.gov.br/wpcontent/uploads/2015/03/Portaria-nb0124.80.pdf>. Acesso em: 09 abr. 2016.

BRASIL. Resolução CONAMA 04/1995. Estabelece que as propriedades vizinhas dos aeródromos e as instalações de auxílio à navegação aérea estão sujeitas a restrições especiais. Disponível em: <http://www.mma.gov.br/port/conama/res/ res95/res0495.html>. Acesso em: 09 abr. 2016.

CETESB. Índice de Qualidade de Aterros de Resíduos Sólidos, IQR. Inventário estadual de resíduos sólidos domiciliares. CETESB, 2014.

EMBRAPA. Brasil em Relevo. Disponível em: <http://www.relevobr.cnpm.embrapa.br/do wnload/>. Acesso em: 29 nov. 2014. 
IBGE. Geociências. Disponível em: <http://downloads.ibge.gov.br/downloads_g eociencias.htm>. Acesso em: 28 fev. 2016.

LINO, I. C. Seleção de áreas para implantação de aterros sanitários: análise comparativa de métodos. Rio Claro: Universidade Estadual Paulista, 2007. Disponível em: <http://repositorio.unesp.br/bitstream/handl e/11449/92745/lino_ic_me_rcla.pdf?sequen ce $=1>$. Acesso em 09 abr. 2016.

MOREIRA, M. A. A. Aplicação de técnicas de geoprocessamento para seleção de áreas para a disposição de resíduos sólidos em aterro sanitário no município de Descalvado (SP). 2002. 144p. Dissertação (Mestrado em Engenharia Urbana) - Departamento de Engenharia Civil. Universidade Federal de São Carlos, São Carlos. 2002. Disponível em: <http://www.bdtd.ufscar.br/htdocs/tedeSim plificado//tde_busca/arquivo.php?codArquiv o=1050>. Acesso em 09 abr. 2016.

SERVIÇO GEOLÓGICO DO BRASIL. Arquivos vetoriais. Disponível em: <http://geobank.cprm.gov.br>. Acesso em: 28 fev. 2016.

WEBER, E.; HASENACK, H. Avaliação de áreas para instalação de aterro sanitário através de analises em SIG com classificação continua dos dados. Porto Alegre: UFRGS, $2000 . \quad$ Disponível em: <http://www2.sorocaba.unesp.br/professor/ robertow/Arquivos\%202011/SIG_2011/SIG_a terros_sanitarios2.pdf>. Acesso em 09 abr. 2016. 